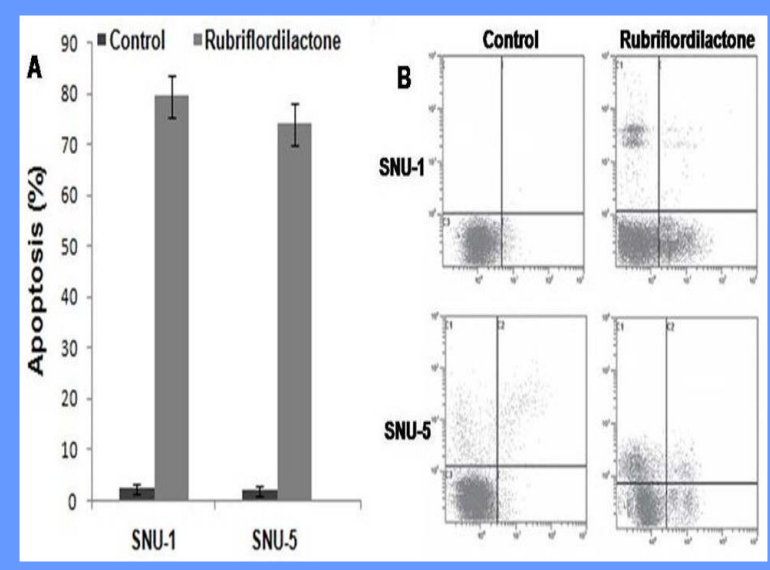

BJP

Bangladesh Journal of Pharmacology

Research Article

\title{
Inhibition of cell proliferation in gastric cancer cell lines on exposure to rubriflordilactone $\mathrm{A}$
}


Abstracted/indexed in Academic Search Complete, Asia Journals Online, Bangladesh Journals Online, Biological Abstracts, BIOSIS Previews, CAB Abstracts, Current Abstracts, Directory of Open Access Journals, EMBASE/Excerpta Medica, Google Scholar, HINARI (WHO), International Pharmaceutical Abstracts, Open J-gate, Science Citation Index Expanded, SCOPUS and Social Sciences Citation Index;

\title{
Inhibition of cell proliferation in gastric cancer cell lines on exposure to rubriflordilactone $\mathrm{A}$
}

\author{
Shang-Jin Peng' and Jue-Wei Chen ${ }^{2}$ \\ ${ }^{1}$ Department of General Surgery, Jinshan Hospital of Fudan University, Shanghai 201508 , China; ${ }^{2}$ Department of \\ Burns and Plastic Surgery, Jinshan Hospital of Fudan University, Shanghai 201 508, China.
}

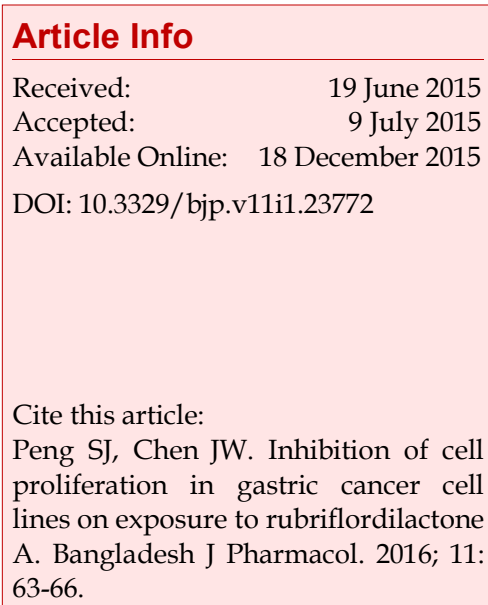

\begin{abstract}
The present study investigates the effect of rubriflordilactone $\mathrm{A}$ on the viability and its underlying mechanism in gastric cancer cell lines (SNU-1 and SNU-5) and normal gastric epithelial cell line (GES-1). Incubation of the gastric cancer and non cancer cell lines in acidic media led to reduction in the viability of the non cancer cells without any effect on cancer cells. Apoptosis in SNU-1 and SNU-5 cells was induced on exposure to rubriflordilactone A after 48 hours compared to the control cells $(p<0.01)$. The percentage of apoptosis in SNU-1 and SNU-5 cells on exposure to rubriflordilactone A was $79.3 \pm 4.7$ and $74.0 \pm 5.1$, respectively after 48 hours. Exposure of SNU-1 and SNU-5 cancer cell lines to rubriflordilactone A at a concentration of $10 \mu \mathrm{M}$ in media with acidic $\mathrm{pH}$ decreased phosphorylation of ERK $1 / 2$. The similar reduction was caused by ERK $1 / 2$ phosphorylation inhibition, PD98059. Thus rubriflordilactone A reduces viability of gastric cancer cell lines by inducing apoptosis through the reduction of ERK $1 / 2$ phosphorylation.
\end{abstract}

\section{Introduction}

Gastric cancer is the most commonly detected and one of the leading cause of cancer deaths throughout the globe (Ferlay et al., 2010; Jemal et al., 2010). In Asian countries the rate of gastric cancer deaths is higher at present compared to the African countries (Jemal et al., 2011; Sun et al., 2004). The major limitation of chemotherapy is the development of drug resistance and appearance of the adverse effects (Wagner et al., 2006). Thus, the discovery of new molecules for the treatment of gastric cancer is highly desired.

Rubriflordilactones A (Figure 1) from isolated from the Schisandra rubriflora that has been widely used in Chinese herbal medicine (Xiao et al., 2006). It exhibits promising anti-HIV activity and antitumor activity (Xiao et al., 2006). In the present study, the effect of rubriflordilactone $\mathrm{A}$ on the viability and induction of apoptosis in the gastric cancer cells is for the first time investigated. Taking clue from the literature that plant derived natural products play an important role in the inhibition of various types of cancers (Ji et al., 2008; Majewska et al., 2006; Zhong et al., 2003; Zhong et al., 2004; Abdullaev and Espinosa-Aguirre, 2004; Das et al., 2010).

Gastric cancer cells are usually present in an environment with acidic pH (Stubbs et al., 1999; Stubbs et al., 1994). Higher rate of proliferation in gastric cancer cells accompanied by faster rates of glycolysis results production of molecules acidic in nature (Holm et al., 1995; Vaupel et al., 1989). Since the increased concentration of acid molecules inside the cells is harmful for their growth and proliferation, these cells eliminate the protons into outer environment (Tannock and Rotin, 1989; Helmlinger et al., 1997).

\section{Materials and Methods \\ Cell lines and culture}

Human gastric cancer cell lines (SNU-1 and SNU-5) and normal human gastric epithelial cell line (GES-1) were 


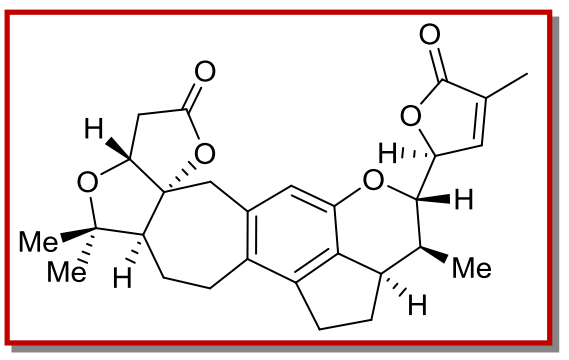

Figure 1: Structure of rubriflordilactone A

obtained from the CLS Cell Lines Service (Eppelheim, Germany). The cells were maintained in Dulbecco's modified Eagle's medium (DMEM; Gibco Life Technologies) supplemented with 10\% FCS in an incubator at $37^{\circ} \mathrm{C}$ in a $5 \% \mathrm{CO}_{2}$ humidified atmosphere.

\section{Reagents}

Rubriflordilactone A, a natural product, was isolated from Schisandra rubriflora. ERK 1/2 inhibitor and other common chemicals were purchased from Merck (Germany).

\section{Cell viability assay}

Rubriflordilactone A-induced inhibition of cell viability in gastric carcinoma cell lines was examined using the CellTiter 96® AQueous One Solution Cell Proliferation (MTS) assay (Promega Corporation, Madison, WI, USA). For this purpose, cells were distributed at a density of $2.5 \times 10^{5}$ into 96 -well microtiter plates. After incubation, the medium was replaced with DMEM medium containing rubriflordilactone $\mathrm{A}$ and incubated for a period of 24 hours at $37^{\circ} \mathrm{C}$. The control cells were treated with DMSO alone. EnVision multilabel plate reader (Perkin-Elmer, USA) was used to measure the absorbance at $565 \mathrm{~nm}$ in the wells containing cells and medium without cells. The experiments were carried out three times.

\section{Reverse transcription polymerase chain reaction (RT-PCR) analysis}

The TRIzol reagent (Beyotime Institute of Biotechnology, China) was used for the isolation of total cell RNA as per the manual protocol. The $2 \mu \mathrm{g}$ RNA samples were used to transcribe cDNA by employing reverse transcriptase kit (Beyotime Institute of Biotechnology). After amplification, the electrophoresis on $1 \%$ agarose gel was followed by visualization using ethidium bromide staining.

\section{Annexin V-propidium iodide assay}

Effect of rubriflordilactone A on the induction of apoptosis in gastric carcinoma cell lines was investigated using FITC conjugated annexin V-propidium iodide apoptosis detection kit (BD Biosciences, Italy). The cells were distributed at a density of $2 \times 10^{5}$ in 6-well plates and treated with $10 \mu \mathrm{M}$ concentration of rubriflordilactone A for 48 hours. The cells, after phosphate buffer solution washing, were immersed in binding buffer supplemented with annexin $\mathrm{V}$ and propidium iodide. The cells were then incubated in dark atmosphere for 20 min and analyzed by the FACSCanto I flow cytometer (BD Biosciences) for the cell apoptosis.

\section{Western blotting}

The cells treated with rubriflordilactone A and DMSO as control were washed with phosphate buffer solution followed by lysis in buffer (50 mM HEPES, $\mathrm{pH} 7.5,150$ $\mathrm{mM} \mathrm{NaCl}, 10 \%$ glycerol, $1 \%$ Triton X-100, $1.5 \mathrm{mM}$ $\mathrm{MgCl}_{2}, 5 \mathrm{mM}$ EGTA, $4 \mathrm{mM}$ phenylmethylsulfonyl fluoride, $1 \%$ aprotinin, $10 \mathrm{mM}$ sodium orthovanadate, $20 \mathrm{mM}$ sodium pyrophosphate). The cell lysates were centrifuged at $12,000 \mathrm{xg}$ at $4^{\circ} \mathrm{C}$ for $20 \mathrm{~min}$ to isolate the supernatant. Coomassie Protein Assay Reagent kit (Pierce, USA) was used for the determination of protein content. The proteins were resolved onto the 13\% SDSPAGE followed by electro-blotting on nitrocellulose membranes (GE Healthcare Life Science, Milan, Italy). The membranes were incubated in non-fat milk in TBS (10 mM Tris-HCl pH 8, 150 mM NaCl, 0.05\% Tween-20) and then for overnight with the primary antibodies for phosphorylated-ERK and total ERK (Cell Signaling Technology, Beverly, MA, USA) overnight at $4^{\circ} \mathrm{C}$. After washing with TBS the membranes were incubated with peroxidase-conjugated specific secondary antibodies for 1 hour. The enhanced chemiluminescence (ECL) system (Genespin Srl., Italy) was used for the visualization of the bands.

\section{Statistical analysis}

The SPSS 12.0 statistical software for Windows (SPSS Inc., Chicago, IL, USA) was used for the statistical analysis. Student's t-test or one-way analysis of variance (ANOVA) and Tukey's or Dunnett's T3 post hoc analysis were used to determine the differences between mean values. The differences at $p<0.05$ were considered statistically significant.

\section{Results}

Behavior of gastric cancer and non-cancer cells in culture media with acidic $p H$

Incubation of the SNU-1 and SNU-5 cell lines and GES- 1 cell line in the media with acidic $\mathrm{pH}$ revealed a marked decrease in the viability of non-cancer cell line compared to two cancer cell lines. The viability of SNU1, SNU-5 and GES-1 cell lines at a pH of 5.5 was found to be $98.7,97.7$ and $34.7 \%$ respectively after 24 hours (Figure 2).

\section{Inhibition of gastric cancer cell viability in acid media by rubriflordilactone $A$}

Exposure of the gastric cancer cell lines, SNU-1 and SNU-5 cultured in acid media to $10 \mu \mathrm{M}$ concentration of rubriflordilactone A for 24 hours led to a significant reduction in the viability of these cell lines (Figure 3). 


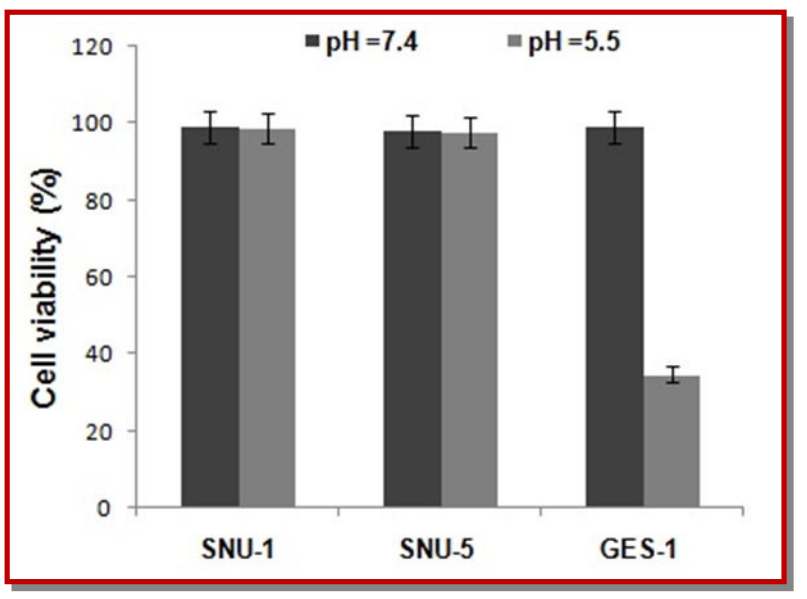

Figure 2: Viability of the gastric cancer and non-cancer cells in acidic media. The viability of cancer cells remained un-effected in acidic media

The viability of SNU-1 and SNU-5 cell lines was reduced to be 23.4 and $22.0 \%$ respectively on treatment with rubriflordilactone A for 24 hours.

\section{Rubriflordilactone A induces apoptosis in SNU-1 and SNU-5, gastric cancer cells}

Treatment of SNU-1 and SNU-5 cell lines with $10 \mu \mathrm{M}$ rubriflordilactone A for 48 hours resulted in the induction of apoptotic cell death. The results from flow cytometry using annexin V-FITC/PI staining clearly revealed apoptosis in SNU-1 and SNU-5 cells exposed to rubriflordilactone A after 48 hours compared to the control cells $(\mathrm{p}<0.01)$ (Figure 4$)$. The percentage of apoptotic cells in the rubriflordilactone A treated and untreated control SNU-1 cells were $79.3 \pm 4.7$ and $2.3 \pm$ $0.5 \%$, respectively after 48 hours. Similarly in SNU-5 cells, the percentage of apoptotic cells was found to be $74.0 \pm 5.1$ and $2.0 \pm 0.8 \%$ in the rubriflordilactone Atreated and untreated cells, respectively after 48 hours.

Inhibition of ERK1/2 phosphorylation in human gastric cancer cells by rubriflordilactone A

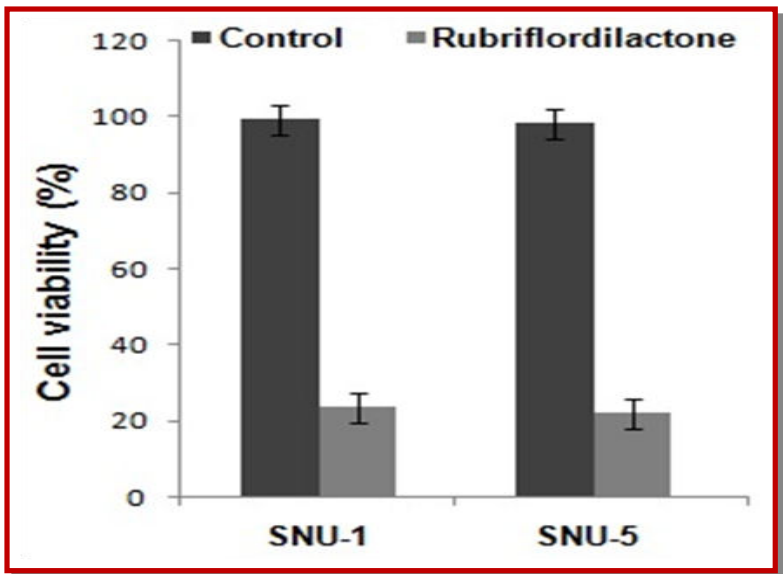

Figure 3: Rubriflordilactone A treatment reduced the viability of cancer cell in acidic media after 24 hours

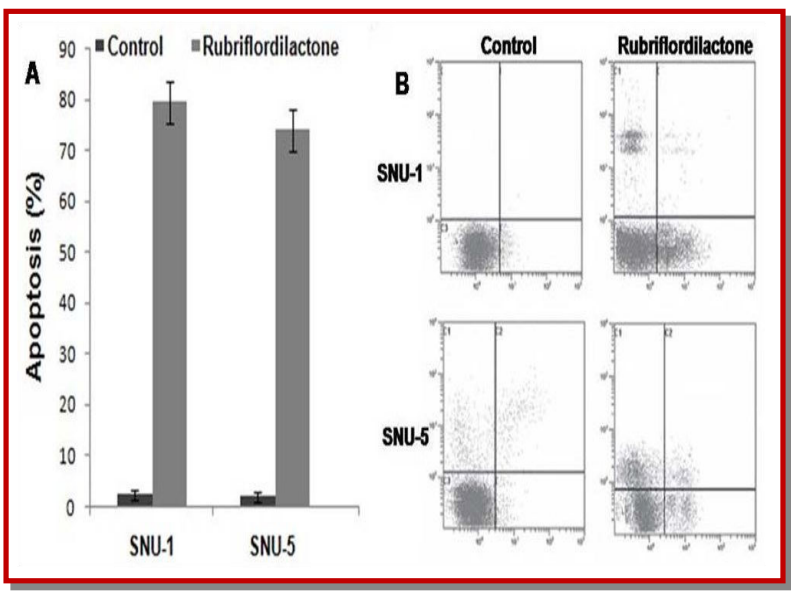

Figure 4: Effect of rubriflordilactone A on induction of apoptosis in SNU-1 SNU-5 and cancer cell line after 48 hours

Exposure of SNU-1 and SNU-5 cancer cell lines to rubriflordilactone $\mathrm{A}$ at a concentration of $10 \mu \mathrm{M}$ in media with acidic $\mathrm{pH}$ led to a significant decrease in the phosphorylation of ERK $1 / 2$ (Figure 5A). These findings suggest that rubriflordilactone $\mathrm{A}$ induces apoptosis in SNU-1 and SNU-5 cells through inhibition of ERK $1 / 2$ phosphorylation. For confirmation of the involvement of ERK $1 / 2$ phosphorylation inhibition in apoptotic cell death, the cells were treated with ERK 1/2 inhibitor, PD98059 at $\mathrm{pH} 5.4 \quad(\mathrm{p}<0.05)$. The results showed a significant reduction in the viability of both the cell lines on treatment with PD98059 compared to untreated cells. Similar results were seen when SNU-1 and SNU-5 cells were treated with rubriflordilactone A (Figure 5B). These results confirm that the rubriflordilactone $\mathrm{A}$ induced apoptosis is caused by the inhibition of ERK $1 / 2$ phosphorylation.

\section{Discussion}

The environment surrounding the carcinoma cells is usually acidic because of faster rate of proliferation leading to anerobic oxidation of food stuff (Trédan et al., 2007; De Milito and Fais, 2005). The results from the present study revealed that the viability of normal cells was reduced markedly in the acidic medium compared to cancer cells. It is believed that the molecules which can reach to the acidic sites and induce apoptosis in the

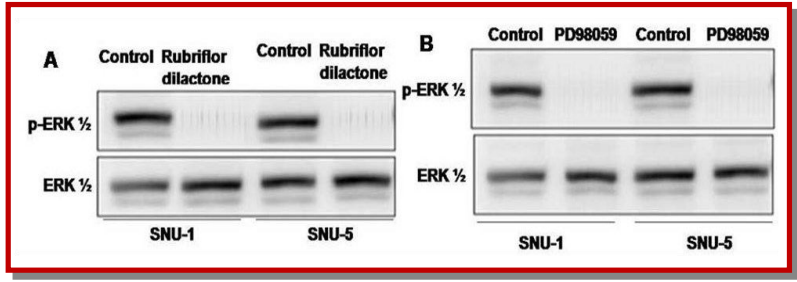

Figure 5: Rubriflordilactone A induced suppression in $\mathrm{p}$-ERK $1 / 2$ expression in SNU-1 and SNU-5 cancer cell lines. (B) ERK $1 / 2$ inhibitor, PD98059 inhibited expression of p-ERK 1/2 in SNU-1 and SNU-5 cancer cell lines 
cancer cells can be of potential value for the treatment of gastric cancer (Fais et al., 2007). In the present study, it was observed that rubriflordilactone A reduced the viability of the SNU-1 and SNU-5 gastric cancer cells in the acidic media. Rubriflordilactone A treatment also induced apoptosis in the gastric cancer cells in the acidic media to the marked extent.

It is reported that the process of apoptosis and proliferation in cancer cells mostly involve MAPK pathway (Kim and Choi, 2010). Among MAPKs, the expression of ERK $1 / 2$ is higher in the cancer cells and has a dominant role in the progression of the cancer (Ballif and Blenis, 2001). However, results from the present study revealed that rubriflordilactone A treatment caused a marked reduction in the expression of phosphorylated ERK $1 / 2$ in the carcinoma cells. Treatment of the gastric carcinoma cell lines with PD98059 which is an inhibitor of ERK 1/2, lead to decrease in the expression of p-ERK $1 / 2$ in the manner similar to that of rubriflordilactone A. Therefore, it appears that rubriflor -dilactone A-induced apoptotic cell death in the gastric cancer cells may partly be due to inhibition of expression of the $\mathrm{p}$-ERK $1 / 2$.

\section{Conclusion}

Rubriflordilactone A can attenuate cell viability via the induction of apoptosis in human gastric cancer cells. The mechanism underlying this antiproliferative effect of rubriflordilactone $\mathrm{A}$ involves the inhibition of ERK $1 / 2$ phosphorylation in gastric cancer cells.

\section{References}

Abdullaev FI, Espinosa-Aguirre JJ. Biomedical properties of saffron and its potential use in cancer therapy and chemopre -vention trials. Cancer Detect Prev. 2004; 28: 426-32.

Ballif BA, Blenis J. Molecular mechanisms mediating mammalian mitogen-activated protein kinase (MAPK) kinase (MEK) -MAPK cell survival signals. Cell Growth Differ. 2001; 12: 397-408.

Das I, Das S, Saha T. Saffron suppresses oxidative stress in DMBA-induced skin carcinoma: A histopathological study. Acta Histochem. 2010; 112: 317-27.

De Milito A, Fais S. Tumor acidity, chemoresistance and proton pump inhibitors. Future Oncol. 2005; 1: 779-86.

Fais S, De Milito A, You H, Qin W. Targeting vacuolar H+ - ATPases as a new strategy against cancer. Cancer Res. 2007; 67: 10627-30.

Ferlay J, Shin HR, Bray F, Forman D, Mathers C, Parkin DM. Estimates of worldwide burden of cancer in 2008: GLOBOCAN 2008. Int J Cancer. 2010; 127: 2893-917.

Helmlinger G, Yuan F, Dellian M, Jain RK. Interstitial pH and $\mathrm{pO}_{2}$ gradients in solid tumors in vivo: High-resolution measurements reveal a lack of correlation. Nat Med. 1997; 3: 17782.
Holm E, Hagmüller E, Staedt U, et al. Substrate balances across colonic carcinomas in humans. Cancer Res. 1995; 55: 1373-78.

Jemal A, Siegel R, Xu J, Ward E. Cancer statistics, 2010. CA Cancer J Clin. 2010; 60: 277-300.

Jemal A, Bray F, Center MM, Ferlay J, Ward E, Forman D. Global cancer statistics. CA Cancer J Clin. 2011; 61: 69-90.

Ji YB, Gao SY, Ji CF, Zou X. Induction of apoptosis in HepG2 cells by solanine and Bcl-2 protein. J Ethnopharmacol. 2008; 115: 194-202.

Kim EK, Choi EJ. Pathological roles of MAPK signaling pathways in human diseases. Biochim Biophys Acta. 2010; 1802: 396-405.

Majewska A, Hoser G, Furmanowa M, Urbańska N, Pietrosiuk A, Zobel A, Kuraś M. Antiproliferative and antimitotic effect, $S$ phase accumulation and induction of apoptosis and necrosis after treatment of extract from Rhodiola rosea rhizomes on HL-60 cells. J Ethnopharmacol. 2006; 103: 43-52.

Stubbs M, McSheehy PM, Griffiths JR. Causes and consequences of acidic $\mathrm{pH}$ in tumors: A magnetic resonance study. Adv Enzyme Regul. 1999; 39: 13-30.

Stubbs M, Rodrigues L, Howe FA, et al. Metabolic consequences of a reversed $\mathrm{pH}$ gradient in rat tumors. Cancer Res 1994; 54: 4011-16.

Sun X, Mu R, Zhou YS, et al. Analysis of mortality rate of stomach cancer and its trend in twenty years in China. Zhonghua Zhong Liu Za Zhi. 2004; 26: 4-9.

Tannock IF, Rotin D. Acid $\mathrm{pH}$ in tumors and its potential for therapeutic exploitation. Cancer Res. 1989; 49: 4373-84.

Trédan O, Galmarini CM, Patel K, Tannock IF. Drug resistance and the solid tumor microenvironment. J Natl Cancer Inst. 2007; 99: 1441-54.

Vaupel P, Kallinowski F, Okunieff P. Blood flow, oxygen and nutrient supply, and metabolic microenvironment of human tumors: A review. Cancer Res. 1989; 49: 6449-65.

Wagner AD, Grothe W, Haerting J, et al. Chemotherapy in advanced gastric cancer: A systematic review and metaanalysis based on aggregate data. J Clin Oncol. 2006; 24: 2903 -09 .

Xiao WL, Yang LM, Gong NB, Wu L, Wang RR, Pu JX, Li, XL, Huang SX, Zheng YT, Li RT, Lu Y, Zheng QT, Sun HD. Rubriflordilactones A and B, two novel bisnortriterpenoids from Schisandra rubriflora and their biological activities. Org Lett. 2006; 8: 991-94.

Zhong L, Qu G, Li P, Han J, Guo D. Induction of apoptosis and G2/M cell cycle arrest by gleditsioside E from Gleditsia sinensis in HL-60 cells. Planta Med. 2003; 69: 561-63.

Zhong L, Li P, Han J, Qu G, Guo D. Structure-activity relationships of saponins from Gleditsia sinensis in cytotoxicity and induction of apoptosis. Planta Med. 2004; 70: 797-802.

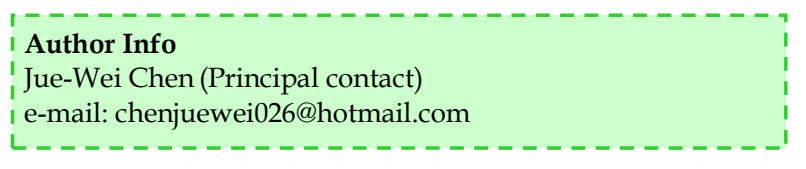




\section{Your feedback about this paper}

1. Number of times you have read this paper 0

2. Quality of paper Click

3. Your comments

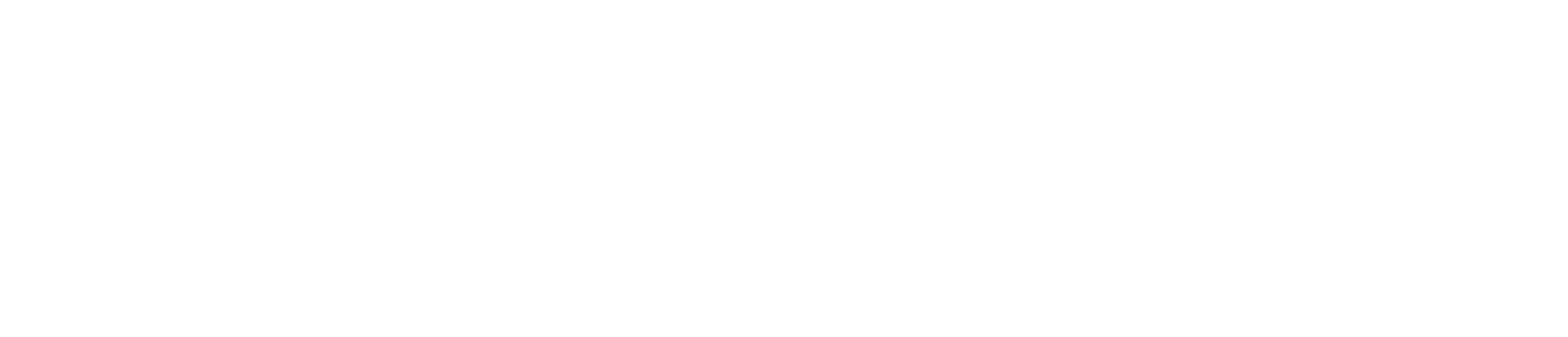

